\title{
THE SOURCES OF BUSINESS INTEREST IN SOCIAL INSURANCE Sectoral versus National Differences
}

\author{
By ISABELA MARES
}

W HAT factors explain the preferences of employers toward various policies of social insurance? When and why have employers supported the creation of policies that provide insurance benefits to workers who experience various employment-related risks? These important questions for the political history of the modern welfare state have been largely overlooked by political economists and social policy scholars. Most studies on the development of systems of social protection have assumed that employers oppose the expansion of social insurance. Business, it has commonly been argued, has left its imprint on the political history of the modern welfare state by opposing the demands of labor-based organizations or by counteracting the administrative largesse of bureaucratic officials. The dominant research tradition on the development of modern institutions of social insurance has characterized the expansion of the welfare state as "politics against markets"the political triumph of labor-based organizations over a political community of employers forced into retreat. ${ }^{1}$

This article challenges the assumption of business opposition to social insurance that has informed comparative research on the welfare state. Its main objective is to develop a theory of the social policy preferences of firms that specifies the conditions under which profitmaximizing firms, facing competition in domestic or international markets, nevertheless support various institutions of social insurance. What is the importance of social policies to firms? Is the welfare state only a constraint that imposes higher costs or unnecessary labor-market rigidities on firms, or does it also provide employers with some direct and tangible benefits? What precisely are the institutional advantages social policies can offer to firms? Under what conditions do these ad-

\footnotetext{
${ }^{1}$ Gøsta Esping-Andersen, Politics against Markets (Princeton: Princeton University Press, 1985); Gøsta Esping-Andersen and Walter Korpi, "From Poor Relief towards Institutional Welfare States: The Development of Scandinavian Social Policy," in Robert Eriksson, ed., The Scandinavian Model: Welfare States and Welfare Research (New York: Sharpe, 1985).
}

World Politics 55 (January 2003), 229-58 
vantages exceed the costs imposed by social policies on firms? The analysis seeks to identify the factors affecting the cost-benefit calculations made by different firms facing the introduction of a new social policy.

An important goal of the article is to identify the factors affecting the variation in the social policy preferences of firms. What variables explain the cleavages within the business community during different episodes of social policy reform? Existing political economy research examining the policy preferences of employers toward wage-bargaining institutions and other labor-market policies presents two competing hypotheses about the nature of the variation in the policy preferences of employers. One set of studies has identified the existence of strong cross-national variation in employers' policy preferences. ${ }^{2}$ Recent research on the role of employers in labor-market reforms of the last two decades finds a strong divergence in the preferences of employers in liberal market economies (such as the U.K. or the U.S.) and employers in coordinated market economies (such as Germany, Austria, the Netherlands, or Northern European countries). These studies suggest that employers in the United Kingdom and the United States have embraced radical proposals for labor-market deregulation and the weakening of the power of trade unions. ${ }^{3}$ As Stewart Wood argues, in "liberal market economies, employers' preference is to weaken organized labor as much as possible. Where firms do not rely upon production strategies that render organized labor a virtue-in collective bargaining or managing process innovation, for example-they will see strong trade unions and strong employment protection as fetters on their ability to compete on the basis of lowering production costs." ${ }^{4} \mathrm{By}$ contrast, employers in Germany or other Northern European economies have shown only lukewarm support for attempts at radical labor market reforms and have defended a variety of non-market-based institutions protecting labor. ${ }^{5}$ According to Wood:

\footnotetext{
${ }^{2}$ See Stewart Wood, "Business, Government and Patterns of Labor Market Policy in Britain and the Federal Republic of Germany," in Peter Hall and David Soskice, eds., Varieties of Capitalism (Oxford: Oxford University Press, 2001); and Margarita Estevez-Abe, Torben Iversen, and David Soskice, "Social Protection and the Formation of Skills," also in Hall and Soskice.

${ }^{3}$ Desmond King and Stewart Wood, "The Political Economy of Neoliberalism: Britain and the United States in the 1980's," in Herbert Kitschelt et al., eds., Continuity and Change in Contemporary Capitalism (Cambridge: Cambridge University Press, 1999); Robert Boyer, The Search for Labor Market Flexibility (Oxford: Clarendon Press, 1988).

${ }^{4}$ Wood (fn. 2), 252.

${ }^{5}$ Philip Manow, "New Coalitions in Welfare State Reforms," in Paul Pierson, ed., The New Politics of the Welfare State (Oxford: Oxford University Press, 2000), 161; Kathleen Thelen,"Why German Employers Cannot Bring Themselves to Dismantle the German Model," in Torben Iversen et al., eds., Unions, Employers and Central Banks (Cambridge: Cambridge University Press, 2000).
} 
In coordinated market economies, product market, innovation and workorganization strategies depend upon collaboration with organized labor. One key role of public policy is therefore to maintain framework legislation that protects workers' organizations and protects their role as partners in negotiated outcomes... This in turn gives employers incentives to participate in the provision of the relevant supply-side collective goods and the governance structures that make this possible. ${ }^{6}$

Other studies have argued that the most significant variables explaining the variation in the policy preferences of firms are located at the sectoral level. In a pioneering study that examines the role played by employers in the centralization of the wage-bargaining system in Denmark and Sweden, Peter Swenson argues that large export-dependent firms supported a highly centralized wage-bargaining system as means of preventing sheltered producers from attracting workers by offering higher wages. ${ }^{7}$ However, the institutional advantages provided by the centralized system of wage bargaining to Swedish export employers eroded over time. Unions' pursuit of intrafirm and intersectoral wage leveling undermined the ability of firms to "secure an adequate supply of motivated labor to the export sector." A strong intersectoral conflict among Swedish employers flared up at the beginning of the 1980s, as manufacturing employers pushed for a stronger decentralization of wage bargaining, in an effort to secure more flexible pay structures. Kathleen Thelen's study of the evolution of German institutions of wage bargaining during recent decades also points to the "activation of a previously dormant cleavage within key employers' associations" over the advantages of the existing institutions of wage bargaining. While large manufacturing employers are "unwilling to abandon the German model," due to the high vulnerability of firms to overt labor conflict, Thelen finds that Germany's small and medium-size firms of the Mittelstand have "been growingly disgruntled" with the architecture of the German wage-bargaining system. ${ }^{10}$

This article develops and tests a model of the policy preferences of firms toward different policies of social insurance. It examines the most important calculations faced by employers during the development of a new social policy and specifies the factors that explain the variation in

\footnotetext{
${ }^{6}$ Wood (fn. 2), 252.

${ }^{7}$ Swenson, "Bringing Capital Back In, or Social Democracy Reconsidered: Employer Power, CrossClass Alliances, and the Centralization of Industrial Relations in Denmark and Sweden," World Politics 43 (July 1991).

${ }^{8}$ Jonas Pontusson and Peter Swenson, "Labor Markets, Production Strategies and Wage Bargaining Institutions," Comparative Political Studies 29 (April 1996), 232.

${ }^{9}$ Thelen, "Varieties of Labor Politics," in Hall and Soskice (fn. 2), 83.

${ }^{10}$ Ibid., 84.
} 
firms' social policy preferences. What is the relative importance of national-level versus sectoral variables in predicting the social policy demands of firms? To explore these questions, the remainder of the article is organized as follows. I begin by presenting the most salient questions of policy design confronted by employers during the introduction of a new social policy. Next I formulate a series of hypotheses about the variables affecting employer preferences. These explanations are tested by examining the demands of French and German employers during three episodes of social policy development: the introduction of compulsory accident insurance (during the 1880s-90s), the development of unemployment insurance (during the 1920s), and the reorganization of social insurance during the first years of the postwar period (1945-48).

\section{The Social Policy Space}

Social insurance policies come in a variety of institutional forms. Some policies are organized by private actors, such as trade unions, mutual aid societies, firms, or associations of producers. Other policies are administered exclusively by the state. Some policies have narrow pools of beneficiaries. In other cases, the entire population is eligible for benefits. Some policies provide meager benefits and are characterized by stringent eligibility conditions. In other cases, social policies replace most, if not all, the income lost by the worker because of employment-related risks, such as sickness or disability.

A set of simplifications is necessary to guide us through this thick institutional terrain. I begin by assuming that existing social policies can be represented in a two-dimensional social policy space. Social policy is defined broadly to include both private and publicly financed social insurance. The two axes of the social policy space represent the two questions of policy design that were politically most contested in the history of the welfare state: (1) the scope of social insurance coverage and (2) the distribution of responsibility for the administration of social insurance. The percentage of the population that has access to social policy benefits varies considerably over time, across countries, and, within the same country, across different labor-market risks. As Peter Baldwin reminds us, only some welfare states "went from Bismarck to Beveridge. ... Insurance has existed for millennia, social insurance developed in response to the widespread and multiple uncertainties attendant on modern economies, while the solidaristic welfare state of a Marshallian kind has been the exclusive preserve of only a few nations at certain 
times in the twentieth century." 11 A few examples can illustrate the wide variation in the scope of social insurance coverage. At the turn of the twentieth century, after a first wave of social policy reforms pioneered by the Bismarckian legislation, the percentage of the labor force entitled to social policy benefits in case of occupational injuries was as high as 71 percent in Germany, 39 percent in Britain, and about 15 percent in Austria, Denmark, Norway, and Switzerland. ${ }^{12}$ At the onset of the Great Depression the percentage of the workforce eligible for unemployment benefits was 58 percent in the United Kingdom, 44 percent in Germany, 34 percent in Austria, and about 20 percent in Belgium, Denmark, Italy, and Switzerland. ${ }^{13}$

The horizontal axis of the social policy space represented in Figure 1 is labeled risk redistribution. 'This dimension captures both the existing variety in the scope of social insurance and the diversity in the modes by which social policies reapportion the incidence and costs of various risks among labor-market participants. The positioning of various social policies along this horizontal axis results from a combination of decisions concerning two interrelated questions of policy design. The first concerns the size of social insurance coverage. How wide is the level of coverage and who is eligible for benefits? Is social policy restricted to the participants of a single firm? Is social insurance mandatory for the entire population of a country-or are certain groups and occupations ineligible for social policy benefits? Second, the degree of risk redistribution of a social policy is influenced by additional policy decisions that determine the relationship between the incidence of a risk and the level of social insurance contributions. Are social insurance contributions calculated solely on the basis of actuarial principles? The degree of risk redistribution of a social policy is lower if social insurance contributions are tightly coupled to the incidence of a risk; it is higher in the case of social policies that loosen this relationship.

The second, separate question of policy design concerns the distribution of responsibilities in the administration of social insurance among bureaucratic representatives, on the one hand, and unions and employers, on the other hand. In 1908 the main publication of the Central Federation of German Trade Unions referred to these "administrative questions (Verwaltungsfragen)" as the "key element in the de-

\footnotetext{
${ }^{11}$ Baldwin, The Politics of Social Solidarity: Class Bases of the European Welfare State, 1875- 1975 (Cambridge: Cambridge University Press, 1990), 5.

${ }^{12}$ Peter Flora and Jens Alber, State, Economy and Society in Western Europe (Frankfurt: Campus, 1983), 460.

${ }^{13}$ Ibid., 461.
} 


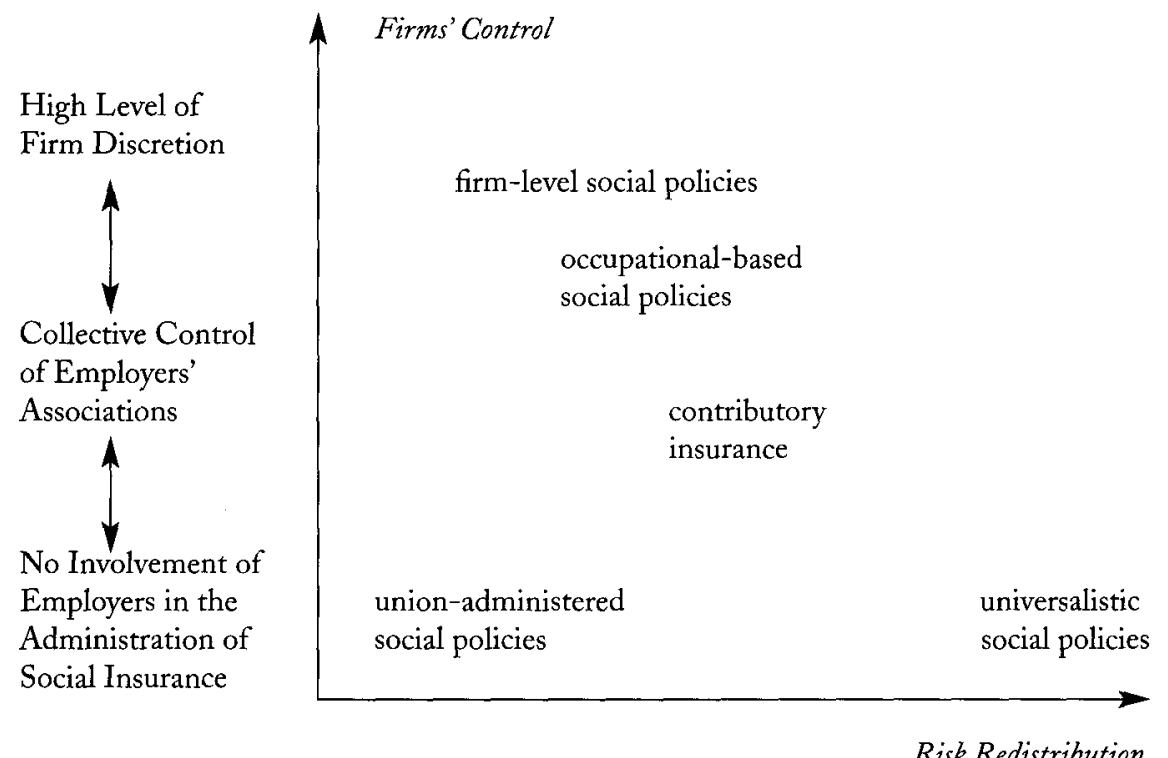

Risk Redistribution

FiguRE 1

The Social Policy Space

sign of social insurance. ${ }^{11}$ This issue has been one of the most divisive political questions throughout the history of welfare state development. Consequently, social policies vary tremendously in the adopted institutional solutions. In some cases--such as Ghent policies of unemployment insurance-the entire responsibility for administering unemployment benefits rests with the trade unions. Means-tested policies of social assistance or universalistic social policies are administered by state bureaucrats, with no participation of trade union or employer representatives. Contributory social insurance policies or occupation-based social policies can be administered in a "corporatist" fashion by trade union and employers' associations (with or without involvement of the state). Finally, some social policies can be administered by individual firms. This is the case of "private" social policies-such as pensions, sickness, or housing policies.

I label the vertical axis of the social policy space control. We can think of control as authority over policy decisions concerning the determination of the level of insurance contributions and benefits, adjustments in the financing of social policy in response to the expansion or contrac-

\footnotetext{
${ }^{14}$ Allgemeiner Deutscher Gewerkschaftsbund, Correspondenzblatt der Generalkommission der Gewerkschaften Deutschlands (Berlin: Legion, December 1902), 308.
} 
tion of the contributory base of social insurance, the modification of administrative criteria defining the entitlement for social policy benefits, and so on. Without any loss of generality, we can recode this axis as measuring responsibilities in the administration of social insurance retained by one of these three actors. The vertical axis in Figure 1 represents the residual responsibilities in the administration of social insurance retained by individual firms. Private social policies are found at one extreme of this axis. In these cases, individual firms can retain unlimited discretion over all policy decisions. In the case of policies taking intermediate values along this dimension, associations of employers administer social policies together with trade unions. This principle of the corporatist organization of social insurance was pioneered during the early social policy reforms in Germany during the 1880s and adopted by a large number of countries in the design of their insurance systems. Finally, in social policies that take extremely low values along this dimension of the social policy space, employers are entirely absent from the administration of social insurance. The most significant policy decisions remain in the hands of either trade unions or government officials.

In Figure 1 a variety of social policies are positioned within the policy space bounded by the two axes: risk redistribution and control. At one extreme we find universalistic social policies that take high values on the risk redistribution axis and low values on the control dimension of the social policy space. The entire population is entitled to social policy benefits, guaranteeing de facto that the "community of risks coincides with the entire human community." ${ }^{15}$ Neither individual firms nor business associations play a role in the administration of social policies. Consequently, these policies take zero values along the control axis of the social policy space. At the other extreme of the social policy space, we find private social policies. Social insurance coverage is restricted to the employees of the particular firm. In these cases the firm retains a high level of discretion in targeting these benefits at the highly skilled or the highly productive workers or in withholding these benefits from employees considered to be less productive. Thus, the administrative discretion retained by the firm is maximal.

Various contributory insurance policies can be situated along a line linking private-type social policies to universalistic social policies. In contrast to private social policies, employers' associations (and not individual firms) participate in the administration of the particular social

${ }^{15}$ Baldwin (fn. 11), 3 . 
policy. ${ }^{16}$ Some contributory insurance policies can be very close to the universalistic pole of the social policy space. In this case employers' associations retain only a very limited (and sometimes only symbolic) role in the administration of the social policy. The level of risk redistribution of this policy can be very high, if social insurance contributions are uniform across occupations and not linked to the incidence of the risk affecting the particular occupation and if the level of social insurance coverage is very broad. Conversely, we find contributory insurance policies that are closer to private-type social policies. In this case social insurance coverage is more limited in scope and a variety of occupations do not have access to social policy benefits. The social insurance contributions are linked to the incidence of a risk and we find no redistribution of risks across occupations.

Two additional observations about Figure 1 are necessary. First, social policies taking simultaneously high values along both axes, risk redistribution and control, do not exist. A hypothetical example of a policy situated in the upper-right-hand corner of the policy space would be a social policy that is entirely administered by a firm with no participation of labor representatives or the state but that remains universalistic in character. Such policies remain historically unknown. Second, the diagonal axis in Figure 1-linking private social policies to contributory insurance and universalistic social policies-points to a policy trade-off between risk redistribution and control. When confronted with the introduction of a new social policy, employers are never able to achieve a maximal level of risk redistribution and control at the same time. Policies in which firms' control is maximal (private social policies) are ultimately incompatible with a very high level of risk redistribution. Conversely, in policies characterized by a high level of risk redistribution (universalistic social policies), control is very low. In examining the social policy preferences of employers, we need to explore the conditions under which different firms prefer different combinations of risk redistribution and control.

\footnotetext{
${ }^{16}$ The importance of employers' associations in the administration of contributory insurance policies varies tremendously across policies. For example, the Bismarckian reforms, which pioneered the principle of a "corporatist" administration of social insurance, gave employers' representatives one-half of the number of seats in the institutions administering old-age insurance and one-third of the seats in the supervisory councils of sickness insurance. By contrast, accident insurance was administered entirely by employers' associations, with no involvement of trade union representatives or the state. A potential conflict can emerge between employers' associations (preferring collective control) and large firms (who favor firm-level control). How this conflict is resolved depends on (1) the sanctioning instruments of the associations and (2) the importance of social policy to the firm. Thus, in the case of disability insurance, the introduction of compulsory insurance largely ended private social policies. By contrast, in the case of early retirement policies, employers' associations were not able to stop the process of firm-level early retirement.
} 


\section{The Social Policy Preferences of EMPloyers}

We now turn to the question of business preferences toward different institutions of social insurance. Under what conditions do profitmaximizing firms, facing competition in domestic or international markets, nevertheless support the adoption of various policies of social insurance? What institutional benefits do employees obtain from social policy? The starting point of my analysis is the observation that social policies mitigate the reluctance of workers to invest in skills. To invest in skills, a worker needs income protection for when the employment relationship is temporarily interrupted, such as periods of sickness, disability, or unemployment. It is rational for employers to commit resources to policies of social protection to induce workers to make these investments in skills. Policies of social insurance with earnings-related benefits that replace a significant part of the income lost by the workers provide these institutional guarantees and give workers incentives to undertake these risky investments in skills. Thus, a social policy that insures workers for employment-related risks also protects the investment made by employers in the skills of their workers.

This hypothesis suggests that the benefits provided by social policies to employers can outweigh the costs imposed by social policies on firms, if the firm wants workers to invest in skills. But what are the implications for the social policy preferences of firms? When will firms prefer more private-type social policies and when will they prefer more redistributive social policies? What are the most significant factors affecting the utility of firms along the two dimensions of the social policy space outlined in the previous section? To answer these questions, I examine the calculations made by firms confronted with a choice of different social policies.

As discussed above, the vertical axis of the social policy space measures the residual responsibilities in the administrative control of social insurance retained by a firm. What are the costs for an individual firm associated with an upward movement along this axis? An increase in the level of control retained by employers in the administration of social insurance increases firms' share in the financing of the social policy. Universalistic social policies are generally financed by income taxes and thus affect employers only indirectly, via their impact on the general price level of the economy. By contrast, contributory insurance policies are financed by payroll taxes. Generally, the distribution of the tax burden among employers and employees is proportional to the responsibilities of these actors in the administration of the particular branch of social insurance. Finally, private social policies can be financed by a 
combination of contributions from employers and employees or by employers' contributions alone. Thus, private social policies or contributory insurance solutions can be costlier to firms than universalistic or means-tested social policies.

What benefits do employers derive from an increased involvement in the administration of social insurance? The most obvious institutional advantage is an increase in their discretion in important social policy decisions. Social policies can become an important instrument complementing the employment practices of firms. Firms gain additional flexibility to rely on social policies both during periods of labormarket shortages and during periods of unemployment. Policies taking high values along the control dimension of the social policy space-private social policies or contributory insurance-provide a second distinct institutional advantage to employers. This derives from the tight coupling between the social insurance benefits and the wage-hierarchy established within the firm. Earnings-related social policy benefits raise the relative reservation wage of high-skilled workers (relative to lowskilled workers), lowering the incentives of these workers to take up jobs that do not correspond to their skill qualifications. By mitigating the incentives of high-skilled workers to take up jobs that do not correspond to their skill qualifications, these policy instruments provide indirect institutional guarantees to employers that their investment in skills will not be undermined during periods in which workers are temporarily out of work. Third, firms may seek higher levels of control in the administration of social insurance to counteract a potential increase in the institutional prerogatives of trade unions and to shift the balance of political power away from organized labor. During the imperial period the peak federation of German employers' associations (Vereinigung der Deutschen Arbeitgeberverbände) referred to the Ghent policy of unemployment assistance as a "hidden subsidization of the strike funds of trade unions [verkappte Streikunterstützung]" and strongly opposed social policies that gave unions a role in the administration of social policy benefits. ${ }^{17}$ During the first years of the postwar period, employers in many countries strongly opposed policy proposals that increased the representation of labor in the administration of social

\footnotetext{
17 "Von der Arbeitslosenversicherung," Der Arbeitgeber, December 1, 1913. For similar considerations, see also “Das Problem der Arbeitslosenversicherung," Der Arbeitgeber, January 1, 1910; Vereinigung der Deutschen Arbeitgeberverbände, Geschäftsbericht der Vereinigung der Deutschen Arbeitgeberverbände (Berlin: VDA 1927), 160. It is important to point out, however, that employers have not always opposed policies with no control on the part of firms, such as Ghent policies. On small firms' support for Ghent policies, see Isabela Mares, "Strategic Alliances and Social Policy Reform: Unemployment Insurance in Comparative Perspective," Politics and Society 28, no. 2 (2000).
} 
insurance. This suggests that employers' motivation to support contributory social insurance policies may be stronger in economies that have strong, well-organized trade unions.

This suggests that the utility of the firms along the vertical dimension of the social policy space can have both a positive and a negative sign, depending on the relative magnitude of the benefits and the costs of control to a firm. What factors influence the cost calculations made by firms? A first variable that is likely to affect the relative importance of these policy instruments to the firm is the firm's skill profile. A natural hypothesis is that the presence of skilled workers within the firm increases the importance of those policy features that protect the investment in skills. It is likely that employers who have invested significant resources in the skills of their workers will favor social policies that allow them to target benefits to a select group of workers and reward their job performance. A second variable that will likely affect the costbenefit calculations made by firms is the size of the firm. A number of empirical studies have suggested that firm size is a strong predictor of the degree of market power. ${ }^{18}$ Thus, assuming a higher market power of large firms, we can hypothesize that these producers will have a greater capacity than small producers to shift an increase in their nonwage labor costs onto consumers in the form of higher prices. ${ }^{19}$ This severely constrains the ability of small firms to invest resources in the creation of social policy programs. Because of these financial constraints, small firms are more likely to discount the potential institutional advantages of many institutions of social insurance and to focus instead on the financial burden of these policies. By contrast, we expect large firms to discount more readily the adverse effects of an increase in the level of payroll taxes. ${ }^{20}$

\footnotetext{
${ }^{18}$ In other words, monopolistic behavior is more likely in industries where the average firm size is higher. See Dennis Carlton and Jeffrey Perloff, Modern Industrial Organization (New York: Harper Collins 1994), 187-88. This assumption might not be fulfilled, however, during early historical periods, when markets were not fully integrated and when small firms enjoyed a near monopoly in local markets. Two factors that work against the effects of the fragmentation of the product markets during the early period of industrialization are (1) the presence of economies of scale (in some industries such as steel and railroads) and (2) the existence of cartel-type agreements among large producers. These factors increase the degree of market power of large firms despite the fragmentation of product markets. Beginning in the 1880 s in both France and Germany, cartel-like arrangements were pervasive in industries such as iron and steel or railroads. See, for example, Karl Brandt, "Konzentration und wirtschaftliche Entwicklung," in Helmut Arndt, ed., Die Konzentration in der Wirtschaft (Berlin: Duncker and Humblot, 1971); Wolfram Fischer and Peter Czada, "Wandlungen in der Deutschen Industriestrukture im 20. Jahrhundert," in Gerhard Ritter, ed., Entstebung und Wandel der modernen Gesellschaft (Berlin: Gruyter, 1970), 146-49; Jacques Houssiaux, Le pouvoir du monopole (Paris: Sirey, 1978).

${ }^{19}$ This is a standard comparative statics result in a Cournot model of competition; see Carlton and Perioff (fn. 18), 233-34.

${ }^{20}$ Other studies have suggested additional reasons why large firms are more likely than small producers to support the introduction of social policies. In a study of the social policy preferences of
} 
The empirical implication of the above discussion is that large firms employing skilled workers will favor social policies characterized by higher levels of control, while small firms employing low-skilled workers will discount the potential institutional advantages of control. The analysis does not generate unambiguous predictions for small firms employing skilled workers and large firms whose workforce consists preponderantly of low-skilled workers. I predict, however, that these firms will experience very strong policy dilemmas and a strong tension between the potential institutional advantages of social policies and the costs of social insurance. Hence, one would likely see greater variability in the preferences of these firms. Characteristic examples are the small, highly skill-intensive Handwerk firms in Germany. As the empirical analysis will demonstrate, on some occasions these firms have supported social policies characterized by high levels of control. On other occasions, these firms have opposed the introduction of such policies, fearing an increase in their nonwage labor costs. During the last decades of the nineteenth century, Handwerk firms strongly opposed the introduction of the compulsory social insurance. However, during the first years of the postwar period these firms have supported the Bismarckian policy status quo and opposed proposals to reduce the role of employers in the administration of social insurance.

How does the utility of firms vary along the risk redistribution dimension of the social policy space? How do employers choose among different social policies characterized by similar levels of control but different levels of risk redistribution? What variables influence their preferences? As discussed above, a movement along the horizontal dimension of the social policy space from private to universalistic social policies involves an expansion of the risk pool of social insurance and a weakening of the insurance principle in the determination of the levels of contributions. In policies that take high values along this axis, the determination of the level of insurance contributions is not based on actuarial criteria alone. Thus, to characterize the preferences of employers along this dimension of the social policy space, we need to specify the relative magnitude of two separate effects, the setup costs of a social policy versus the benefits associated with participating in a broader pool of risks.

American employers regarding the Clinton health care plan, Cathie Jo Martin found that "large firms are more likely to develop a supportive position on health reform. Size matters because larger firms may be more willing to avoid labor strife. Larger companies are more likely to have economies of scale in political action"; Martin, "Nature or Nurture? Sources of Firm Preference for National Health Reform," American Political Science Review 89 (December 1995), 900. 
I hypothesize that employer preferences on these questions of policy design will be influenced by relative incidence of the risks affecting their workforce. The relative incidence of a risk can be measured as the difference between the incidence of a risk facing a firm's workforce and the average at the level of the economy. I hypothesize that an increase in the relative incidence of a risk will potentially increase the benefits of participating in a common pool of risks. For these firms, private forms of insurance are often ineffective, since sharing "good" and "bad" risks is rarely possible in these narrow risk pools. By contrast, for employers facing a low incidence of risks, social policies characterized by high levels of risk redistribution will be unattractive, since these policies turn these firms into subsidizers of high-risk industries. These propositions have specific implications for the details of social policy design favored by different producers. We expect low-risk producers to favor occupational social policies or contributory social insurance policies in which the social insurance contributions of employers are determined on the basis of strict actuarial considerations, thus, social policies that involve no redistribution of risks across occupations. In contrast, we expect high-risk producers to favor social insurance policies characterized by a high redistribution of risks. These are contributory insurance policies in which the level of insurance contributions is not linked to the incidence of a risk or universalistic social policies.

The analysis so far has identified a number of independent variables affecting the utility of firms along the two dimensions of the social policy space. It predicts the emergence of significant intersectoral conflict among employers during the introduction of a new social policy. I have hypothesized that the size and skill intensity of a firm will increase the relative benefits of social policies characterized by high levels of control. Large firms employing high-skilled workers are hypothesized to favor social policies characterized by high levels of control. By contrast, small firms that have not invested significant resources in the training of the workforce will find the institutional advantages of social policies characterized by high levels of control to be less attractive. The model does not generate unambiguous predictions for the cases of large firms with a low-skill workforce and small firms with a high-skill workforce. We expect a high variability in the social policy preferences of these firms. I have also hypothesized that an increase in the risk incidence will increase the benefits of risk redistribution for a firm. Figure 2 summarizes these hypotheses about the utility of firms.

An alternative explanation locates the most important source of variation in the social policy preferences of employers at the national level. 
WORLD POLITICS

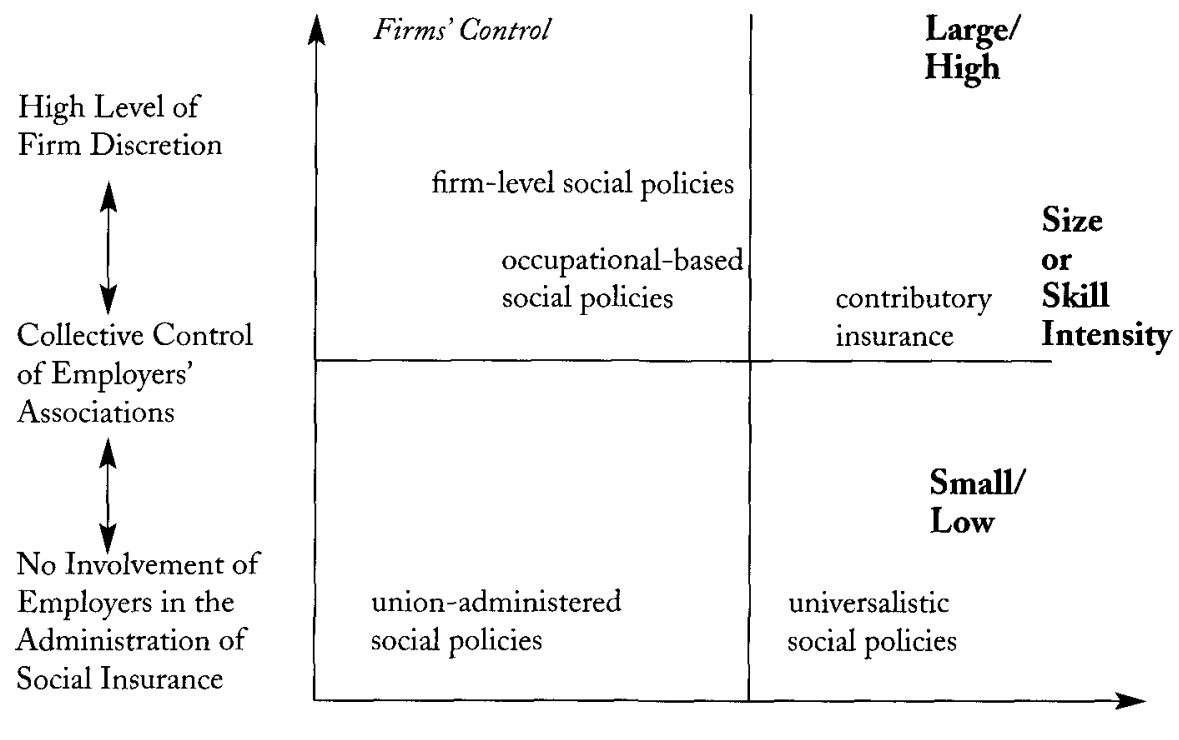

Risk Redistribution

\section{Low High}

Incidence of Risk

FIGURE 2

Predictions about Social Policy Preferences of Firms

Recent studies of varieties of capitalism have implications for firm preferences about institutions of social insurance. According to these studies, in economies with weak business organizations (such as the U.S., the U.K., or France) employers are unable to solve a broad range of collective action problems in the provision of skills and do not invest significant resources in training their workers. By contrast, in economies characterized by a dense network of institutions of business coordination (such as Germany or the Scandinavian countries), employers invest significantly larger resources in the training and skill formation of their workers. Varieties of capitalism studies hypothesize that employers in coordinated market economies are likely to support policies of social protection, because such policies mitigate the reluctance of workers to invest in nontransferable, firm-specific skills, which can be rendered obsolete by technological shocks. ${ }^{21}$ As Estevez-Abe, Iversen, and Sos-

\footnotetext{
${ }^{21}$ For a formulation of these hypotheses, see Peter Hall and David Soskice, "An Introduction to Varieties of Capitalism," in Hall and Soskice (fn. 2); Estevez-Abe, Iversen, and Soskice (fn. 2).
} 
kice argue: "If firms want to be competitive in product markets that require an abundance of specific skills, workers must be willing to acquire these skills at the cost of increasing their dependence on a particular employer or group of employers. Because investment in these specific skills increases workers' exposure to risks, only by insuring against such risks can firms satisfy their need for specific skills." 22 The implication of these hypotheses is that employers in coordinated market economies will support policies of social protection, while employers in noncoordinated market economies will oppose them. ${ }^{23}$

\section{An Empirical Test: What Factors Explain the Policy PREFERENCES OF FIRMS?}

The theoretical implications of the model outlined in the previous section will now be tested using the following research strategy. In an effort to increase variation along the crucial independent variables, I have selected Germany and France as country-cases. ${ }^{24}$ Historically, the German and French economies have differed strongly in their industrial structure and in the mix of large and small firms. Until the wave of modernization that began in the late 1950s, the French economy had been dominated by agricultural small producers. ${ }^{25}$ For example, in 1896, 72 percent of all French employers were agricultural employers; in 1921, the ratio was 78 percent. ${ }^{26}$ In France agriculture represented 44.8 percent of the labor force in 1896 and 41.54 percent in 1921, respectively. According to data collected by French labor-market authorities, in the late nineteenth century more than 60 percent of the French labor force was employed in enterprises with fewer than ten employees. ${ }^{27}$ In 1921, 97 percent of French agricultural employers employed fewer than five workers, a figure that remained virtually unchanged in

\footnotetext{
${ }^{22}$ Estevez-Abe, Iversen, and Soskice (fn. 2), 181.

${ }^{23}$ Wood (fn. 2).

${ }^{24}$ See Gary King, Robert Keohane, and Sidney Verba, Designing Social Inquiry: Scientific Inference in Qualitative Research (Princeton: Princeton University Press, 1994), 137. France and Germany are also examples of coordinated and uncoordinated market economies, respectively. As numerous historians of the development of the German political economy have pointed out, the defining institutional characteristics of a coordinated market economy were already in place in the mid-1880s. These included (1) provision of "patient finance" by large banks and (2) strong and encompassing business associations. See, for example, Volker Hentschel, Wirtschaft und Wirtschaftspolitik im wilhelminischen Deutschland. Organisierter Kapitalismus und Interventionsstaat (Stuttgart: Klett-Cotta, 1978); Hans-Peter Ullmann, Interessenverbände in Deutscbland (Frankfurt: Suhrkamp, 1983).

${ }^{25} \mathrm{See}$, for example, Patrick Fridenson and André Straus, Le Capitalisme français au XIX-XXXìme siècle (Paris: Fayard, 1987); Denis Woronoff, Histoire de l'industrie en France (Paris: Seuil, 1994).

${ }^{26}$ Flora and Alber (fn. 12), 497, 501.

${ }^{27}$ République Française, Journal Officiel (Sénat), March 12, 1889, 200.
} 
$1931 .^{28}$ By contrast, in Germany at the turn of the century about 40 percent of the workforce was employed in enterprises with fewer than ten workers; the number declined to 30 percent in 1925 and to 26 percent in $1950 .{ }^{29}$ Historically, Germany and France have also exhibited a strong variation in the skill profile of their workforce. Legislation fostering vocational training goes back in Germany to the 1860 s and $1870 \mathrm{~s}^{30}$ Building on these earlier policies, an important law of 1897 "created a network of handicraft chambers (Handwerkskammern) endowed with extensive powers to regulate the content and quality of craft apprenticeships." ${ }^{11}$ During the same period large German firms developed firm-level vocational schools (private Fachschulen) that responded to their demands for a high-skilled workforce. ${ }^{32}$ Based on some estimates, the percentage of skilled workers exceeded 50 percent of the workforce in some industries (such as metalworking and metal processing). ${ }^{33}$ By contrast, France did not have comparable legislation fostering the development of institutions of skill formation. ${ }^{34}$ Large French firms in "modern" industries-such as metallurgy and chemicals-drew on the large reservoir of unskilled immigrant workers and did not develop extensive internal policies of vocational training. ${ }^{35}$

The sources for the analysis of the social policy preferences of firms are the minutes of the deliberations of employers' associations, various periodicals of employers' associations, and statements and documents submitted by employers' associations to various bureaucratic and parliamentary commissions. The dataset used here is drawn from unpub-

${ }^{28}$ Albert Broder, Histoire économique de la France au XXime siècle (Paris: Ophrys, 1998), 46.

${ }^{29}$ Walther Hoffmann. Das Wachstum der Deutschen Wirtscbaft seit der Mitte des 19. Jabrbunderts (Berlin: Springer, 1965), 212.

${ }^{30}$ See Hans Pohl, Berufiche Aus- und Weiterbildung in der deutschen Wirtschaft seit dem 19. Jabrbundert (Wiesbaden: Steiner, 1979).

${ }^{31}$ Kathleen Thelen and Ikuo Kume, "The Rise of Nonmarket Training Regimes: Germany and Japan Compared," Journal of Japanese Studies 25 (January 1999), 39.

${ }^{32}$ See Gerhard Adelmann, "Die Berufliche Ausbildung und Weiterbildung in der Deutschen Wirtschaft, 1871-1918," in Pohl (fn. 30), 21.

${ }^{33}$ Ibid., 23.

${ }^{34}$ See Patrice Pelpel and Vincent Troger, Histoire de l'enseignement technique (Paris: Hachette, 1993). For postwar developments, see Lucie Tanguy, "Les promoteurs de la formation en enterprise, 1945-1971," Travail et emploi 86 (April 2001).

${ }^{35}$ See Gary Cross, Immigrant Workers in Industrial France: The Making of a New Laboring Class (Philadelphia: Temple University Press, 1983); and Gerard Noiriel, Workers in French Society in the Nineteenth and Twentieth Centuries (Oxford: Berg, 1990). According to statistics reported in Cross, in $1906,17.6$ percent of the workforce in metallurgy and 10 percent of the workforce in the chemical industry were foreign workers (p. 23). As Noiriel pointed out: "The dependence on very large-scale immigration during the 1920s became one of the primary sociological factors underlying the boom in French industry during those years. Immigrant workers were, moreover, most numerous in the most dynamic sectors with the greatest profits" (p. 123). During the interwar period "the proportion of immigrant workers in heavy metal-industry rose to 38.2 percent (in 1931). In the mines, immigrant workers represented 6.5 percent of the labor force in 1906 and 42 percent in 1931" (p. 121). 
lished documents found in the main business and parliamentary archives in France and Germany. ${ }^{36}$ The sample for each policy episode consists of representative sectors of the business community of the period, ${ }^{37}$ including, on the one hand, the most significant federations of employers (such as the Union of Metallurgical and Mining Industries in France and the Central Federation of German Employers' Association in Germany) and of associations representing small firms (the Federation of the German Handwerk, various chambers of commerce), on the other hand.

The theoretical model outlined in the previous section has two main observable implications. First, the model predicts that firm size and the skill profile of the firm will influence the policy preferences of firms about the administrative design of social policies. Second, the model predicts that the incidence of risk will predict firms' preferences along the risk-redistribution dimension of the social policy space. An alternative explanation suggests that the cross-national variation among French and German employers should override possible intersectoral differences. The main implication of the varieties of capitalism literature is that employers in a coordinated market economy (Germany) should support policies of social insurance. French employers, by contrast, are expected to oppose social policies.

\section{The Development of ACCIDENT InSURANCE}

Reform of legislation compensating victims of workplace accidents was a significant issue on the policy agenda of most industrializing countries during the last three decades of the nineteenth century. After the failure of attempts to confine reforms to an incremental change in liability laws, more ambitious proposals that attempted to introduce social insurance moved to the center of the policy agenda. However, issues related to the design of institutions of social insurance raised difficult, nearly intractable dilemmas of policy design. What should be the relative

\footnotetext{
${ }^{36}$ This dataset is based on documents found at the following archives: the Economic Archive of Rheinland-Westfalen (Cologne), the State-archive Dahlem (Berlin), the Federal Archive (Potsdam and Koblenz), the Archive of the Central Federation of German Employers' Association (Cologne). The archival sources in France are the National Archives, the Archive of the Paris Chamber of Commerce (which hosts the archive of the Assembly of Presidents of French Chambers of Commerce), the Archive of the Commission de Représentation Patronale and the Center of Contemporary Archives.

${ }^{37} \mathrm{I}$ analyze the policy preferences of employers in the development of accident, unemployment, and old-age insurance. I have selected these policies to maximize variation in the types of policy trade-offs faced by firms during the introduction of a new social policy. In the cases analyzed below, the set of policy alternatives that are on the agenda of policymakers include policies of social insurance organized by trade unions (in the case of unemployment insurance), private, voluntary insurance (in the case of workplace accidents), and universalistic social policies (in the case of old-age insurance during the postwar period).
} 
role of the state and private actors in the administration of these policies? Should social insurance be mandatory for all industries or only for the mechanical industries facing a high incidence of workplace accidents?

Questions concerning the proper mix between institutions of social insurance administered by the state and "private-type" social policies administered by individual firms or associations of producers were distributionally divisive for employers. In both France and Germany large manufacturing employers preferred a policy outcome that guaranteed the autonomy of preexisting private institutions of social insurance. In both societies large firms or sectoral or regional associations of producers had established private-type policies providing benefits to the victims of workplace accidents. In France the largest institution compensating victims of workplace accidents had been established by the Iron Works Committee (Comité des Forges) and included thirtyone firms. ${ }^{38}$ Faced with proposals to create social insurance, these producers advocated a social policy that guaranteed the autonomy of the policies established by employers. ${ }^{39}$ In Germany the leading peak association representing large manufacturing producers, the Federation of German Industrialists, opposed the monopolization of social insurance by the state. This solution was characterized as "an unnecessary form of state socialism, given the dense network of preexisting institutions of social insurance existing in German society." ${ }^{40}$ The Federation of German Industrialists preferred a corporatist organization of social insurance that entrusted significant administrative responsibilities to associations of employers. ${ }^{41}$

Thus, large manufacturing producers attached high importance to the participation of employers in the administration of social insurance. In exchange for higher control, these employers were prepared to accept higher social insurance contributions. Small firms had the opposite policy priority. The main consideration of these employers was the reduction in their nonwage labor costs. A survey carried out by the Prussian Statistical Office among sixty-one chambers of commerce found only five of them voicing concern about the absence of representation of employers in the new institutions of social insurance. ${ }^{42}$ More

\footnotetext{
38 "L'assurance libre contre les accidents du travail," La Réforme Sociale, June 16, 1893, 961.

${ }^{39}$ See "L'assurance obligatoire allemande et l'assurance libre," La Reforme Sociale, March 1, 1894, 345 .

${ }^{40}$ Verhandlungen, Mitteilungen und Berichte des Centralverbandes Deutscher Industrieller, no. 19 (1883), 149.

${ }^{41}$ Verhandlungen, Mitteilungen und Berichte des Centralverbandes Deutscher Industrieller, no. 28 (1884), 34.

${ }^{42}$ L. Francke, "Die Stimmen der Deutschen Handels- und Gewerbekammern über das Haftpflichtgesetz vom 7. Juni 1871 und den Reichs-Unfallsversicherungs-Gesetzentwurf vom 8.3.1881," Zeitschrift des Königlich-Preussischen Statistischen Büros 21 ( ).
} 
than half of the chambers of commerce in the sample continued to express concerns about the costs of the new social policy. ${ }^{43}$ Several producers argued that "the consequences of the new social insurance legislation were incalculable and highly dangerous" and that the law weakened German industry vis-à-vis foreign competitors. ${ }^{44}$ In France chambers of commerce representing predominantly small firms also opposed the new social insurance, fearing an increase in their nonwage labor costs. As an association of employers formulated these worries, "By preoccupying itself with the situation of workers, the draft bill neglects the numerous and interesting class of employers who will not be able to afford these costs and will succumb as victims to the new incurred responsibility." ${ }^{45}$ Other producers wrote: "We beseech the lawmaker not to inflict a new charge on French industry, on our large and small enterprises, so courageous in their fight against foreign competition... A large number of producers will inevitably be crushed by the impact of a new charge." ${ }^{46}$

The analysis of the social policy preferences expressed by German and French employers supports the second hypothesis about the cleavage between high-risk and low-risk producers. High-risk employers were in those industries facing a high incidence of workplace accidents - such as iron and steel producers - and in mining and railways. In Germany the number of accident fatalities (per 100,000 workers) in these industries was 597 in railways, 261 in mining, 160 in steel production, and 125 in construction. By contrast, the number of workplace accidents in low-risk industries was 18 total in textiles, the paper industry, and the leather industry and 17 in agriculture. ${ }^{47}$ The social policy preferences of high- and low-risk producers differed dramatically. In Germany iron and steel producers were the strongest supporters of a compulsory accident insurance. ${ }^{48}$ These employers supported a social policy solution in which all industries paid similar insurance contributions, irrespective of the incidence of the risk of workplace accidents. Employers in high-risk industries also called for a broad and expansive

\footnotetext{
${ }^{43}$ Ibid., 399.

${ }^{44}$ Chamber of Commerce Braunsberg, in Francke (fn. 42).

${ }^{45}$ Chamber of Commerce of Paris, De la responsabilité des patrons en matière d'accidents, Archive of the Chamber of Commerce of Paris, III. 5. 60 (1).

${ }^{46}$ Chamber of Commerce of Abbevilie, Les accidents du travail: Rapport présenté à la chambre de commerce d'Abbeville par M. Paillart (Paris: CCP, 1898).

${ }^{47}$ Statistics of the period quoted in Florian Tennstedt and Heidi Winter, Quellensammlung zur Geschichte der Deutschen Sozialpolitik: Von der Haftpficbtgesetzgebung zur ersten Unfallversicherungsvorlage (Stuttgart: Gustav Fischer, 1993), 537. There are no similar data available for France. Ironically, French lawmakers relied on these German statistics during the deliberation of the accident insurance legislation.

${ }^{48}$ Verein Deutscher Eisen- und Stahlindustrieller, "Vorstandssitzung des Vereins Deutscher Eisen und Stahlindustrieller," Stabl und Eisen 11 (1884), 177-79.
} 
definition of the risk pool of social insurance, a measure that had the obvious advantage of lowering their social insurance contributions. In a letter submitted to the Chamber of Deputies of the French Parliament, coal producers (Comité Central de Houillières de France) opposed the intention of lawmakers to limit the scope of accident insurance only to industries relying on mechanical tools but recommended instead "[extending] the law to all occupations." ${ }^{49}$ Similarly, German iron and steel producers pressed arguments for extending social insurance to agricultural workers. ${ }^{50}$

In contrast to employers in high-risk industries, employers in industries facing a lower incidence of workplace accidents opposed proposals seeking to socialize insurance. In a petition to the Bundesrat, the Federation of Cotton Employers of Southern Germany (Verein Süddeutscher Baumwollindustrieller) expressed the concern that the first version of the accident insurance legislation under discussion in the Reichstag placed a disproportionate burden on employers in textiles, as opposed to iron and steel producers. ${ }^{51}$ The peak association representing German agricultural employers (Deutscher Landwirtschaftsrat) also worried about the costs attendant on extending social insurance to agriculture. ${ }^{52}$ Similarly, the Society of French Agricultural Employers (Société des Agriculteurs de France) opposed the intention of lawmakers to enlist agricultural producers as part of the social insurance program, denouncing these plans as a measure that protected manufacturing producers but disfavored agriculture: "The agricultural employers will be unable to finance social charges that are that heavy. There is no agricultural employer who can provide the necessary capital." 53

\section{The Development of Unemployment InsuRance}

During the interwar period policymakers in both France and Germany actively pursued a broad range of social policy reforms. In $1918 \mathrm{Ger}-$ many reformed its means-tested policy of unemployment assistance in an effort to cope with the labor-market dislocations of World War I. The failure of this policy to provide adequate relief to unemployed workers motivated German labor-market authorities to replace this

\footnotetext{
${ }^{49} \mathrm{H}$. Darcy, La question des accidents du travail devant le Sénat (Paris: Chaix, 1896), 6.

${ }^{50}$ See various documents quoted in Tennstedt and Winter (fn. 47), 343-49, 279.

${ }^{51}$ Eingabe des Vereins süddeutscher Baumwollindustrieller an den Bundesrat, in Tennstedt and Winter (fn. 47), 554-56.

${ }^{52}$ Denkschrift des Deutschen Landwirtschaftsrates für das Reichsamt des Innern, in Tennstedt and Winter (fn. 47), 531-38.

${ }^{53}$ Michel Augé-Laribé, La politique agricole de la France de 1880 à 1940 (Paris: PUF, 1950), 113.
} 
policy with a policy of unemployment insurance. In France proposals to introduce compulsory unemployment insurance were part of more ambitious proposals to establish compulsory policies of social insurance covering other risks, such as sickness and old age.

As predicted by the above analysis, in both France and Germany large manufacturing producers employing high-skilled workers favored the development of institutions of social insurance that entrusted significant administrative responsibilities to employers. In France the association that provided the most articulate expression of the concerns of large, skill-intensive firms was the Union of Metallurgical and Mining Industries (UIMM), an organization grouping over six thousand firms in "all industries concerning the production and transformation of metals." 54 The UIMM opposed the proposals of French lawmakers to unify all preexisting institutions of social insurance under the administration of the state, arguing that this policy would create a "hotbed of public sector employees." In a report submitted to the Social Policy Commission of the Chamber of Deputies, these producers pointed out that the "fundamental error of the project consisted in neglecting the existing institutions of social insurance which would increase the effectiveness of the law in difficult situations." 55 Instead of a policy organized by the state, the UIMM recommended placing the firm at the foundation of the institutions of social insurance:

The firm shapes the existence of the worker in crucial ways, by determining the level of wages, the kinds of risks to which the worker is exposed, by establishing the strongest bonds of solidarity among workers. It seems natural that the firm should provide the basis for the organization of social insurance.... Enterprises also facilitate the creation of large autonomous and homogenous insurance funds for the provision of old-age benefits. ${ }^{56}$

The peak association representing large German manufacturing (Vereinigung der Deutschen Arbeitgebervebände) - an association dominated by Germany's dynamic metal-processing sectors-also demanded an increase in employers' participation in the new institutions of unemployment insurance and opposed all policy proposals giving trade unions a majority in the administration of the new social policy. ${ }^{57}$ In contrast, large firms in industries with a lower level of skill intensity-

${ }^{54}$ Georges Lefranc, Les organisations patronales en France (Paris: Payot, 1976), 39.

${ }^{55}$ UIMM, Déposition devant la commission des assurances et de prévoyance sociale de la Chambre des députés et le Conseil Supérieur du Travail sur le projet de loi relatif aux assurances sociales, Archive of the Paris Chamber of Commerce, III. 5. 56 (9), 3.

${ }^{56}$ Ibid., 13.

${ }^{57}$ Vereinigung der Deutschen Arbeitgeberverbände, Geschäftsbericht der Vereinigung der Deutschen Arbeitgeberverbände, 1925-1926 (Berlin: VDA, 1927), 136. 
such as cement producers or employers in construction-opposed the introduction of a corporatist compulsory unemployment insurance. ${ }^{58}$

While large manufacturing producers demanded either more privatetype social policies or the delegation of higher administrative responsibilities to employers, associations representing small firms expressed concern about the potential increase in their nonwage labor costs. Out of a sample of twenty-five chambers of commerce representing small producers in France, twenty associations opposed the social insurance project, invoking concerns about a potential increase in their social charges. Commenting on the social insurance project developed by French lawmakers, one French chamber of commerce noted that "the charge on enterprises that will result from the introduction of a contribution totaling 10 percent of the wages will have inevitable repercussion on the price-level of the entire economy. . . . The immediate introduction of a system of insurance covering all social risks will provoke a profound crisis which will affect the very interests which the new legislation attempts to protect." ${ }^{59}$ In Germany numerous political associations representing small manufacturing employers expressed "fundamental reservations about the introduction of unemployment insurance, which creates immense financial burdens for the Reich, Länder, and the communes." 60 The two leading associations representing the interests of small firms opposed the introduction of a policy of unemployment insurance that "weakened the feeling of responsibility and the striving for self-reliance and [that] fosters the tendency towards idleness." ${ }^{61}$

The level of the risk of unemployment is a strong predictor of the variation in the preferences of firms along the risk redistribution dimension of the social policy space. In both France and Germany volatility in employment was highest in manufacturing industries dependent on export markets, such as metal processing and metal working. ${ }^{62}$ By contrast, agriculture was facing a low incidence of unem-

\footnotetext{
${ }^{58}$ On the opposition of construction employers, see Peter Lewek, Arbeitslosigkeit und Arbeitslosenversicherung in der Weimarer Republik, 1918-1927 (Stuttgart: Franz Steiner, 1992), 157. On the opposition of cement producers, see Karl Führer, Arbeitslosigkeit und die Entstebung der Arbeitslosenversicherung in Deutschland, 1902-1927 (Berlin: Colloquim, 1990), 220.

${ }^{59}$ Chamber of Commerce of Belfort, Rapport sur le régime des assurances sociales en préparation devant le Sénat, Archive of the Paris Chamber of Commerce, IIII. 5.50 (9).

${ }^{60}$ Handelskammer zu Altona, Entwurf eines Gesetzes über eine vorläufige Arbeitslosenversicherung, Zentraies Staatsarchiv Potsdam, Reichswirtschaftsrat, 664.

${ }^{61}$ Deutscher Industrie- und Handelstag, Entwurf eines Gesetzes über die Arbeitslosenversicherung, Zentrales Staatsarchiv Potsdam, Reichsarbeitsamt 4311/87-88; Reichsverband des Deutschen Handwerks, Beiträge zu den Mitteln der Erwerbslosenfürsorge, Zentrales Staatsarchiv Potsdam, Reichsarbeitsministerium 1017.

${ }^{62}$ For example, average rates of unemployment in Germany were 10.7 in metalworking, as compared with 0.3 in agriculture. See Drucksachen des Reichstages 2885, 3. Wahlperiode 1926. For France, see Robert Salais et al., L'invention du chômag (Paris: PUF, 1986).
} 
ployment because "producers in the countryside did not respond to changes in the demand of their products by laying off workers, but by adjusting working time." ${ }^{63}$ Beginning in the mid-1920s Germany's high-risk producers exercised a dominant political influence within the Central Association of German Employers' Federation (Vereinigung der Deutschen Arbeitgeberverbände). These employers favored "the expansion of the scope of unemployment insurance legislation" and "the inclusion of good risks [günstige Risiken] within unemployment insurance, in other words, of occupations in which the danger of future unemployment is lower." ${ }^{4}$ They opposed the differentiation of unemployment insurance contributions based on the incidence of risks faced by different industries and rejected "the creation of occupational risk pools [Gefabrenklassen] within unemployment insurance." ${ }^{55}$ In a communication addressed to the Imperial Labor Office in 1920, these employers argued that it was impossible for industries facing high and recurrent levels of unemployment to pay higher unemployment insurance contributions, since "the financial existence of these firms is endangered, both as a result of uncertainty in their labor relations and as a result of an uncertainty in demand. An additional financial burden that would result from the doubling of the insurance contributions should not be attempted." 66

In contrast to these producers, industries facing a low incidence of unemployment opposed highly redistributive policies of unemployment insurance. German associations representing agricultural employers opposed the proposals of lawmakers to include agriculture as part of unemployment insurance. ${ }^{67}$ Referring to the fact that firms paid wages to workers even during the winter months, these employers argued that "the labor market contract of agricultural employees is the best insurance against the risk of unemployment." ${ }^{68}$ In France the two main associations grouping agricultural producers, the Society of French Farmers (Société des Agriculteurs de France) and the National Confederation of Agricultural Associations (Confédération Nationale des Associations Agricoles) strongly opposed the plans of French lawmakers to extend social insurance to agricultural producers. ${ }^{69}$ They waged a

\footnotetext{
${ }^{63}$ Salais et al. (fn. 62), 35.

${ }^{64}$ Vereinigung der Deutschen Arbeitgeberverbände, ed., Gescbäftsbericbt über das Jabr 1922 (Berlin: VDA, 1923), 35 .

${ }^{65}$ Ibid.

${ }^{66}$ Vereinigung der Deutschen Arbeitgeberverbände, Denkschrift der VDA an das Reichsarbeitsministerium 1920, Zentrales Staatsarchiv Potsdam, Reichsarbeitsamt 4310/475.

${ }^{67}$ See statements of associations representing agricultural producers quoted in Führer (fn. 58), 324.

${ }^{68}$ Ibid., 323.

${ }^{69}$ Augé-Laribé (fn. 53), 109-17.
} 
fierce political campaign against the plans-invoking the existence of strong differences in the character of the employment relationship in agriculture and industry, such as "the higher presence of remuneration in kind in agriculture, the reliance of agricultural employers on members of their extended family, as well as the strong individualism of the peasant, which is the result of the profound isolation of work on the field." Instead they favored a policy outcome relying on voluntary institutions of private insurance, such as mutual aid societies (sociétés de secours mutuels) and agricultural mutual insurance companies (mutuelles agricoles) for the provision of social policy benefits.

\section{THE REORGANIZATION OF SOCIAL INSURANCE DURING THE POSTWAR YEARS}

Emboldened by the success of the policy reforms in Britain, policymakers in France and Germany initiated ambitious proposals for social policy reform in the first years after World War II. In France an early bill enacted during the first months of the liberation (Ordonnance of October 1945) proposed unifying the administration of all subsystems of the welfare state. Additional proposals for reform taken up by the French parliament during the following months recommended the introduction of a universalistic social policy. Military authorities governing Germany also considered proposals to introduce universalistic social insurance. These reforms involved far-reaching changes to the "Bismarckian" setup of the welfare state of both countries.

The first important policy change recommended by these new legislative proposals increased the role of the state and labor representatives in the administration of social insurance. These policy recommendations met with strong opposition from German and French employers. In Germany the peak association representing large manufacturing employers defended the importance of "parity representation" of labor and capital in the administration of social insurance as the only solution that could "avoid the concentration of economic power of one group over another." 70 In a policy paper entitled, The Economy and the German Social Insurance, manufacturing employers argued that the administration of social insurance by individual firms or associations of employers had been historically successful in containing the growth of social insurance contributions.

\footnotetext{
${ }^{70}$ Vereinigung der Arbeitgeberverbände, Rundschreiben an den Bundesarbeitsminister Storch betreffend der Selbstverwaltung in der Sozialversicherung, November 29, 1949, BDA Archive, Cologne.
} 
Institutions of sickness insurance organized at the firm level [Betriebskrankenkassen], as well as the liability associations [Berufsgenossenscbaften], determine the level of insurance contributions and reserves based on the risk profile of the firm, which is influenced by the accident-proneness and sickness of the workforce. This has a strong effect on the level of social insurance contributions, as both employers and employees have an interest in lowering the potential burden of high insurance contributions. The concentration of these insurance branches in large, centralized institutions will necessarily decrease the interest of the firm and its employees in reducing the risk of sickness and accidents. $^{71}$

French employers also denounced the "exclusion of business from the administration of family and accident insurance, two branches of social insurance financed primarily by employers." 72 They argued that the administrative centralization of social insurance envisaged by the Ordonnance of 1945 would contribute to a massive increase in costs and bureaucratic delays, the consequence of an arrangement whereby "nonspecialists" would be "administer[ing] three distinct and very different risks: a liability insurance, a social insurance and family benefits." 73 French employers decried the unification of social insurance as an unjustified "trustification of the social," which ironically was attempted at a time when "policymakers declared war on the economic trusts." These findings support the hypotheses advanced in this article that the representation in the administration of social insurance is an important political question for employers.

Both French and German producers opposed the policy proposal that attempted to establish a unique social insurance fund-the Einbeitsversicherung or régime unitaire. ${ }^{75}$ They recommended the separation of various risks within social insurance. In France the social policy committee of the Paris chamber of commerce developed the most detailed recommendations for the separation of the various branches of social insurance. In the case of sickness, old age, and family benefits, these employers recommended organizing social insurance on a "very limited scale," either at the firm level (a solution for large firms) or at the in-

\footnotetext{
${ }^{71}$ Die Wirtschaft und die Deutsche Sozialversicherung, Archive of the Friedrich Ebert Foundation, Walter Auerbach Papers, 11/1, Box 207.

${ }^{72}$ Chamber of Commerce of Paris, Lorganisation de la Sécurité Sociale (Rapport Brossard), Archive of the Paris Chamber of Commerce, III. 5. 70 (1).

${ }^{73}$ Ibid.

${ }^{74}$ Chamber of Commerce of Paris, Un projet d'unification et d'étatisation des institutions de Sécurité Sociale, Archive of the Paris Chamber of Commerce, III. 5. 70 (1).

${ }^{75}$ See Ernst Hilbert, "Was erwarten die Arbeitgeber von der Neuordnung der deutschen Sozialversicherung?" Arbeitsblatt für die britische Besatzungszone 1 (1947), 285-87; BDA, ed., Einheitsversicherung widerlegt, Der Arbeitgeber, 1, 2, 17-19; BDA, ed., "Warum keine Einheitsversicherung?" Der Arbeitgeber (1949), 1, 3, 6-7.
} 
dustry level (to be administered by an association of employers) ${ }^{76}$ In Germany employers' representatives in the social policy committee of the American occupation zone depicted the "concentration of the entire financial apparatus of social insurance in one hand" as a "development with ominous consequences for the creation of democratic institutions." 77 The Federation of Chambers of Commerce of Bavaria drew parallels between the postwar proposals for reform and the policy changes introduced during the period of national socialism, which had removed employers from the administration of social insurance and had extended the "oversight of the Nazi state over all branches of the German welfare state." ${ }^{78}$ Another association of employers argued that "the decentralization of social insurance and the wide variety of existing organizations is a sign of the strength of existing social policies. Different risks necessitate the construction of different institutions of social insurance." $" 79$

The second objective of the reforms initiated by French and German policymakers during the postwar period was the extension of social insurance coverage. The proposed reforms recommended extending social policy benefits to agricultural employees, artisans, and members of liberal occupations. According to a number of studies formulated by German and French social policy authorities, the demographic profile of these groups was significantly worse than the profile of occupations that had been previously insured. ${ }^{80}$ In both countries agriculture was clearly the occupation with the highest old-age dependency ratio, a development that had resulted in part from the migration of younger people to the city. ${ }^{81}$ As pointed out by a policy document drafted by various agricultural interest groups in Germany, "The number of elderly in agriculture is higher than in other occupations." ${ }^{82}$ The artisanal

\footnotetext{
${ }^{76}$ Rapport Brossard (fn. 72), 9.

${ }^{77}$ See Horst Schieckel, ed,, Gegenwartsprobleme der Sozialversicherung (Munich: Richard Pflaum, 1947).

${ }^{78}$ Arbeitsgemeinschaft der bayerischen Industrie- und Handelskammern an dem Bayerischen Landtag un an die Bayerische Staatsregierung und dem Herrn Ministerpräsidenten Dr. Erhard, January 10, 1947, Bundesarchiv Koblenz, Z1/947.

${ }^{79}$ Landesarchiv Südwestdeutschland der gewerblichen Berufsgenossenschaften, April 18, 1946, Bundesarchiv Koblenz, Z1/939.

${ }^{80}$ Schieckel (fn. 77); see also Vereinigung der Industrie- und Handelskammern in der britischen Bestazungszone and das Hauptamt der Arbeitsverwaltung für die britische Zone, December 9, 1948, Rheinisch-Westfälisches Wirtschaftsarchiv, Cologne, RWWA 22 800/00.

${ }^{81}$ On these developments, see Surleau Commission, Rapport sur les travaux de la Commission d'Etudes nommée par la commission chargée d'étudier les modifications a apporter a la loi du 22 mai 1946 portant generalization de la Sécurité Sociale, Centre d'Archives Contemporaines, 1947, SS 07921, 760228, Box 45, Ministère du Travail et de Sécurité Sociale.

${ }^{82}$ Die zwei Seiten der bäuerlichen Altersversicherung, Archive of the Friedrich Ebert Foundation, Auerbach Papers, 240.
} 
sector also faced very unfavorable demographic developments. ${ }^{83}$ Thus, the decision to extend the scope of social insurance was a distributionally divisive decision that favored artisans and agricultural employers and disfavored the manufacturing sector.

The main implication of the theoretical model of business preferences presented in this article is that these higher-risk occupations should favor the expansion of social insurance, while low-risk occupations should oppose it. The empirical findings confirm these hypotheses. Manufacturing employers opposed the policy proposal to extend social insurance. In Germany representatives of large manufacturing producers in the social policy committees of the American occupation zone expressed significant concerns about the capacity of the pension system to finance the benefits of future generations of retirees if this expansion of the coverage were to come about. ${ }^{84}$ The worsening of the risk that was socialized would require either higher social insurance contributions on the part of all employers or a future reduction in the level of the social policy benefits, a decision that was hard to implement politically. As a result, these employers regarded the expansion of the risk pool of social insurance as fraught with ominous implications. ${ }^{85} \mathrm{In}$ France large manufacturing producers also opposed the immediate expansion of social insurance to other industries. Representatives of the Conseil National du Patronat Français regarded the "generalization of social insurance" as the premature expansion of an unearned right and recommended the extension of social assistance benefits as a fiscally more prudent policy solution. ${ }^{86}$ The Union of Metallurgical and Mining Industries (UIMM) also denounced the proposals to expand the level of social insurance coverage as a measure that could potentially bring about the "self-destruction of social security." ${ }^{87}$ High-risk producers welcomed the proposals of lawmakers to extend social policy benefits to broader circles. Agricultural producers in both France and Germany supported the proposals for the "generalization" of social insurance. These demands for social protection of agricultural employers stand in

${ }^{83}$ See Surleau Commission (fn. 81); and Zentralamt für Arbeit (Lemgo), Stellungnahme zur Begründung von Änderungen der geltenden Regelung der Handwerkerversicherung, 1948 Archive of the Friedrich Ebert Foundation, Auerbach Papers, 240.

${ }^{84}$ Erklärung der Arbeitgebervertreter im Sozialpolitischen Ausschuss des Länderrats zum Gutachten der Sachverständigen der amerikanischen Zone über die Neuordnung der Sozialversicherung, in Schieckel (fn. 77), 122-27.

${ }^{85}$ Arbeitgebervertreter (fn. 84).

${ }^{86}$ This is the position of the representatives of the Conseil National du Patronat Français during the deliberations of an extraparliamentary commission (Surleau Commission) discussing these policy changes.

${ }^{87}$ UIMM quoted in Anne-Marie Guillemard, Le déclin du social (Paris: PUF, 1986), 65. 
sharp contrast to the opposition to all institutions of social protection that had been advocated by these sectors during earlier episodes of social policy reform. In Germany several associations representing agricultural employers demanded the introduction of social insurance, arguing that the "burden of old age is particularly heavy in agriculture." ${ }^{8}$ French agricultural producers supported the extension of social insurance as an important provision that could create equal advantages for agriculture and industry. ${ }^{89}$ These employers demanded the introduction of a financial agreement by which the other insurance funds compensate annually the institutions of social insurance in agriculture. In both France and Germany small firms and artisanal producers also supported the compulsory social insurance but recommended important modifications to the policy proposals of policymakers. A document drafted by the Central Federation of German Handwerk in 1949 stressed the importance of social insurance for these firms. "The poverty among Handwerker is so pervasive that we cannot abandon these social policies, despite some worries." ${ }^{\circ 0}$ Representatives of the Handwerk supported the principle of compulsory insurance, but only if each firm were allowed to "choose among different institutions of social insurance based on their own policy needs." In France professional associations representing artisans also supported a compulsory system of social insurance but demanded a stronger separation among the institutions administering various risks. ${ }^{91}$ These findings thus confirm a crucial insight of the model. The incidence of a risk (in this case, the risk of old age) is an important predictor of a sectoral cleavage in the business community.

\section{CONCLUSIONS}

These empirical findings support the hypotheses about the sources of variation in the social policy preferences of firms advanced in this article. In examining the policy preferences of French and German em-

\footnotetext{
${ }^{88}$ Die zwei Seiten der bäuerlichen Altersversicherung (fn. 82); see also Stellungnahme der Landwirtschaft zur Sozialversicherung, n.d., Archive of the Friedrich Ebert Foundation, Auerbach Papers, Box 206.

${ }^{89}$ Centre d'Archives Contemporaines, SS 07921, 760228, Box 45, Ministére du Travail et de Sécurité Sociale, 1947, Note résumant les entretiens avec les différentes organizations des travailleurs independents au sujet de la modification de la loi du 28 mai 1946.

${ }^{90}$ Förderungen zur Altersversorgung des Handwerks, Archive of the Friedrich Ebert Foundation, n.d., Walter Auerbach Papers, Box 240.

${ }^{91}$ Surleau Commission (fn. 81). See also position of Bellanger, vice president of the Assemblée des Présidents des Chambres de Métiers en France, 1946 Archives Nationales, Commission du Travail, Première Assemblée Constituante, C 15293, 25.6.
} 
ployers, I have found a strong intersectoral conflict in the business community. ${ }^{92}$ Large firms in skill-intensive industries have supported institutional design that guaranteed employers a high level of discretion in the administration of social insurance. Small firms, by contrast, have been predominantly concerned with the impact of social policy on their nonwage labor costs. High-risk producers have pushed for the expansion of social insurance coverage. By contrast, low-risk producers have favored social policies characterized by a lower redistribution of risks, such as private-type social policies or policies of social insurance that involved no redistribution of costs across occupations. The model has also been able to explain variation over time in the social policy demands of various sectors. Proposals to introduce compulsory accident and unemployment insurance were unattractive to agricultural producers in both France and Germany, as these employers faced a low incidence of workplace accidents and unemployment, respectively. The shift in the policy preferences of these sectors during the postwar period resulted from a relative worsening of the demographic burden of agriculture. As a result of the change in the relative incidence of the labor-market risks of their workers, these employers became potential "winners" from the introduction of redistributive insurance and supported social policies characterized by a wider coverage.

This article has important implications for the literature on comparative welfare states. It suggests that future research-examining either the historical development of policies of social protection or the recent politics of welfare state adjustment-can no longer be premised on the assumption of business opposition toward social insurance. While much of the past research has emphasized the importance of class conflict in the development of the modern welfare state, future studies will have to pay closer attention to the role of cross-class alliances in the development of a new social policy. To characterize the structure and political composition of these cross-class alliances, future research needs to examine two interrelated questions. Studies of the determinants of the social policy preferences of labor-based associations will have to specify the range of questions of social policy design along which laborbased associations and some sectors of the business community are in agreement and distinguish these from issues which continue to remain

\footnotetext{
${ }^{92}$ Thus, the empirical findings do not support the hypothesis suggesting that the most important variation in the social policy preferences of firms is a cross-national variation. Firms located in different political economies but having similar characteristics (in terms of size and incidence of risks) have supported similar social policies.
} 
distributionally divisive for capital and labor. ${ }^{93}$ Second, future studies need to examine more systematically the broad range of political and institutional variables that facilitate the formation of different crossclass alliances among unions and employers and the causes leading to the political victory of some cross-class alliances over others. Such an analysis of these coalitional dynamics behind social policy development is outside the scope of this article. The article does, however, provide the necessary microfoundations to "bring back" employers to comparative research on the welfare state.

\footnotetext{
${ }^{93}$ The framework developed in this article suggests that the "control" dimension of the social policy space is always distributionally divisive between capital and labor. By contrast, some sectors of the business community might share a common interest with labor-based associations about the level of social insurance coverage and the redistribution of costs across occupations (that is, along the risk redistribution dimension of the social policy space).
} 